\title{
Abandoned Mines Used as Roosts for Reproduction by Townsend's Big-Eared Bats (Corynorhinus townsendii) in a Protected Area in the Central Highlands of Mexico
}

\author{
León-Galván Miguel Angel ${ }^{1}$, Rodríguez-Tobón Ahiezer², Cano Espinoza José Sulim¹, \\ Guzman Ledesma Beatriz Samantha ${ }^{1}$, Guevara-Chumacero Luis Manuel ${ }^{1}$, \\ Leyequien Abarca Lissette ${ }^{3}$
}

\author{
${ }^{1}$ Department of Biology, Autonomous Metropolitan University-Iztapalapa, Mexico \\ ${ }^{2}$ Postgraduate in Experimental Biology, Autonomous Metropolitan University-Iztapalapa, Mexico \\ ${ }^{3}$ Direction of the Sierra La Mojonera Flora and Fauna Protection Area, National Commission of Natural Protected Areas (CONANP), S.L.P. \\ Mexico
}

\section{Email address:}

leon@xanum.uam.mx (León-Galván M. A.), ahiezerrod@yahoo.com.mx (Rodríguez-Tobón A.), sulim.cano@gmail.com (Cano E. J. S.), samantha.guzled@gmail.com (Guzmán L. B. S.), lmgc1@yahoo.com (Guevara-Chumacero L. M.), lleyequien@gmail.com (Leyequien A. L.)

\section{To cite this article:}

León-Galván Miguel Angel, Rodríguez-Tobón Ahiezer, Cano Espinoza José Sulim., Guzman Ledesma Beatriz Samantha, GuevaraChumacero Luis Manuel, and Leyequien Abarca Lissette.. Abandoned Mines Used as Roosts for Reproduction by Townsend's Big-Eared Bats (Corynorhinus townsendii) in a Protected Area in the Central Highlands of Mexico. Animal and Veterinary Sciences. Special Issue: Advances in Bat's Reproduction. Vol. 3, No. 1-1, 2015, pp. 13-21. doi: 10.11648/j.avs.s.2015030101.13

\begin{abstract}
In Chihuahuan Desert arid zone, particularly the states of Zacatecas and San Luis Potosi, Mexico, have been distinguished by its large mining activity, however, many of these mines are disuse, becoming potential refuges for various species of cave bats. Monitoring the potential roosts by Corynorhinus townsendii was made within the system of mines in the vicinity of the Sierra La Mojonera Flora and Fauna Protection Area, at Mexico's Central Highlands in the states of Zacatecas and San Luis Potosi. Which consisted of visual inspection inside, and mist netting at the entrance of different mines during an annual cycle. The main reproductive roosts for $C$. townsendii were identified. Spermatogenesis takes place during MaySeptember; the mating period in November-December, whereas the sequence of gestation-lactation occurred since March to August of the next year. These data confirm that $C$. townsendii in the area of study follow a seasonally monoestrous reproductive pattern, characterized by an asynchrony between the ovarian and spermatogenic cycles.
\end{abstract}

Keywords: Bats, Reproduction, Corynorhinus townsendii, Central Highlands of Mexico, Conservation

\section{Introduction}

The diversity of bat species in Mexico is great, including approximately $12.5 \%$ of all bat species known worldwide $(\approx 1,150)$. These animals can use a wide variety of sites as shelters: hollows in trees or beneath their bark, among the leaves of several plant species, and in rocks and fissures, but primarily inside natural caves. Though indirect, the effects of human activity are reflected in the fact that some bats now occupy artificial refuges for their reproductive activity, such as abandoned construction sites, wells, or mines that are no longer exploited to extract minerals.

The arid zone of the Chihuahua Desert -which begins in the southeastern United States and extends southward into the Mexican states of Zacatecas and San Luis Potosi, where the Mexican High Plains is formed, and flanked by the Sierra Madre Oriental Mountains- is an area well known for extensive mining activity, as from Colonial times it has been an important producer of such minerals as zinc, silver and copper, among others. Today, many of those mines have fallen into disuse and become potential roosting-sites for various species of cave bats $[1,2]$. While the area has a wide variety of vegetation, the most representative types are desert scrubs and temperate coniferous and hardwood forests, which provide abundant food for arthropod populations, especially insects. And these, in turn, constitute the principal food source for insectivore bats. Shelter and food are considered two limiting factors in the biology of bat populations [3], so any place that provides these two key elements may well be 
adequate for reproduction, since sufficient food is available to ensure the energy supplies necessary to carry out basic reproductive processes. For these reasons, such sites must be considered as of high priority for the conservation of this group of mammals [4-6].

Chiroptera species are notable for the variety of their reproductive modes, which range from "seasonal monoestrous" to "continuous polyestrous" patterns [7, 8]. Seasonal bat species have a single reproductive pattern characterized by asynchrony in the timing of the males' and females' respective reproductive cycles, and in the fundamental processes that make up the sexual cycles of the two sexes. This is the case of several temperate-zone insectivorous bats, including species of the American Corynorhinus genus (eg. C. mexicanus, C. rafinesquii, $C$. townsendii). In these bats, spermatogenesis occurs in springsummer, mating in autumn-winter, and births in the spring of the following year [9-11].

These features are particularly characteristic of Townsend's Big-eared bats, whose habitat stretches from the continental United States into southern Mexico, with five recognized sub-species: $C$. $t$. ingens, $C$. $t$. pallescens, $C$. $t$. townsendii, $C$. $t$. virginianus, and $C$. $t$. australis. The distribution of the latter sub-species extends as far south as the state of Oaxaca in Mexico, passing through Mexico's Central Highlands in the states of Zacatecas and San Luis Potosi [12-14].

For several decades, studies have found that C. townsendii populations suffer from the accelerated reduction of their habitats and roosting sites [15]. According to the World
Conservation Union's 2004 IUCN Red List of Threatened Species, all five sub-species of $C$. townsendii are classified as "vulnerable to extinction" (VU) [16]. However, relatively little is known about populations of these bats in Mexico, where they are not listed in any risk category in the Mexican Norm NOM-059-ECOL-2010 [17]. This may be due to the fact that we know so little about their shelters in general and much less about roosts that may serve as active breeding sites. Therefore, the objectives of this study were to: (i) investigate some of the main mines belonging to different mining complexes in the Sierra La Mojonera Flora and Fauna Protection Area region and its hinterland in the Central Highlands of the states of San Luis Potosi and Zacatecas, which can be used as reproduction sites by $C$. townsendii bats; and, (ii) establish the principal reproductive parameters and timing for this species in that area, since reproduction is the main process for perpetuating organisms and species.

\section{Material and Methods}

\subsection{Study Area}

The study was conducted in the Potosino-Zacatecano Central Highlands of Mexico, in the so-called "area of influence" surrounding the "Sierra La Mojonera" (SM), a Protected Area of Flora and Fauna (FFPA), located between $23^{\circ} 54^{\prime}$ and $24^{\circ} 42^{\prime}$ North latitude and $100^{\circ} 42^{\prime}$ and $101^{\circ} 30^{\prime}$ West longitude, in the municipalities of Vanegas in northern San Luis Potosi, and Concepción del Oro in northern Zacatecas (fig.1).

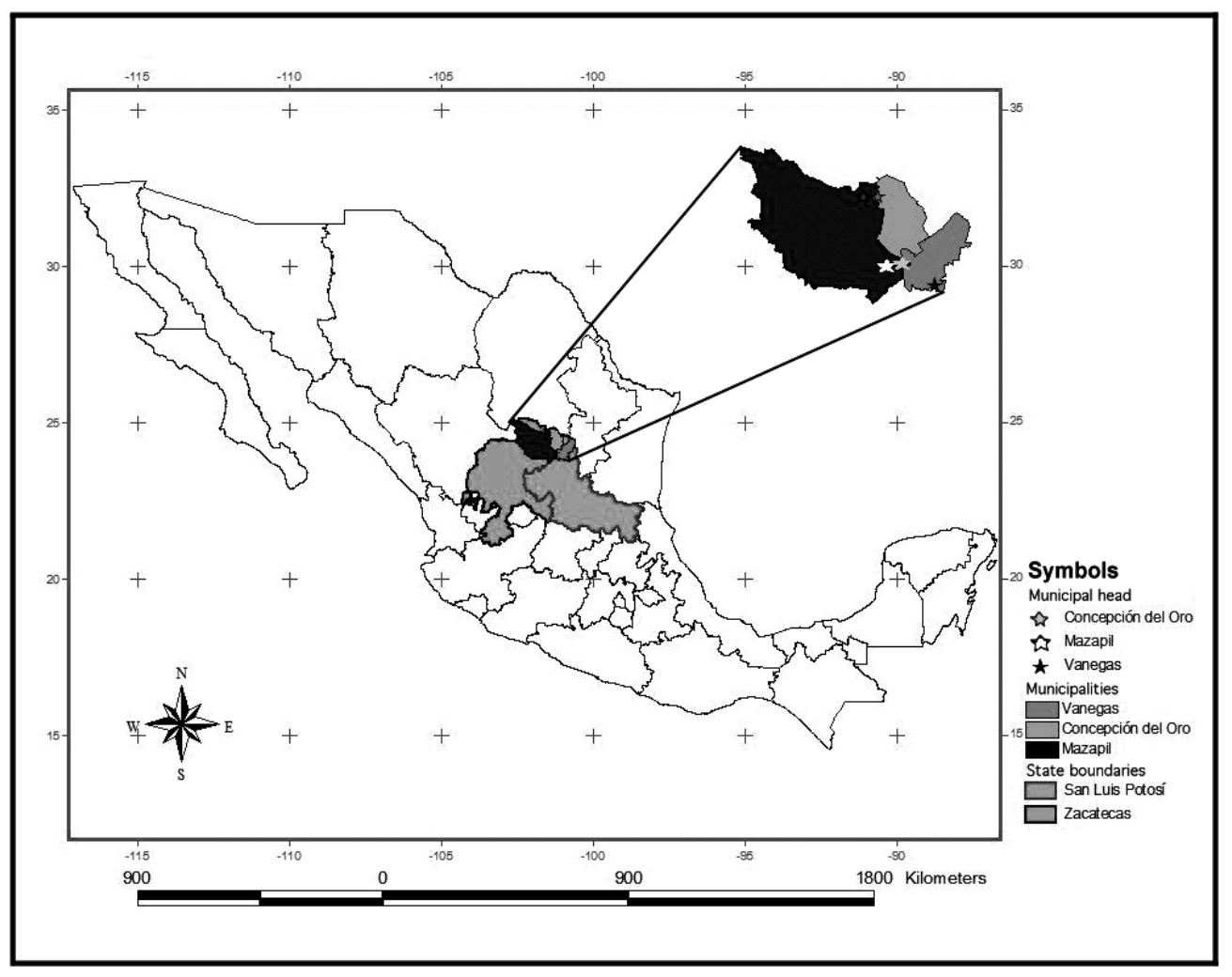

Figure 1. Study area, the Potosino-Zacatecano highland located at the southern border of the Chihuahuan Desert arid zone of Mexico. 


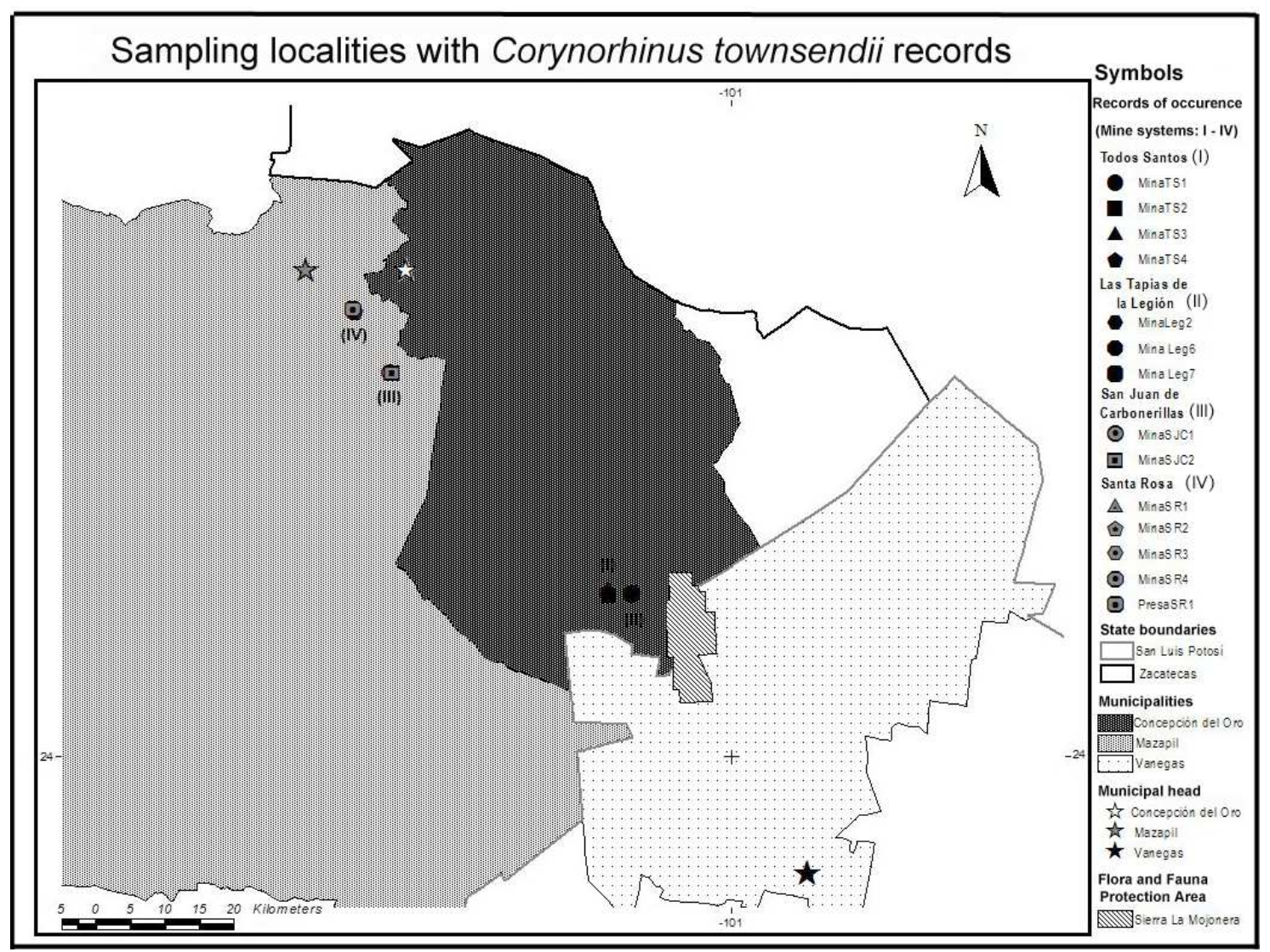

Figure 2. Map of geographic localization of the Sierra La Mojonera Flora and Fauna Protection Area and the influence zone near it, and the distribution of four abandoned mine systems in which some mines are used as roosts by Townsend's Big-eared bats Corynorhinus townsendii.

Because this is an ancient mining region, four different systems of mines were located and selected due to they offered potential shelters for Townsend's big-eared bats in some of the hills that intrude into the central plateau from the Sierra Madre Oriental mountains. Two of these systems -(I) Todos Santos $\left(24^{\circ} 12^{\prime} 31^{\prime} \mathrm{N} ; 101^{\circ} 9^{\prime} 31^{\prime} \mathrm{O}, \approx 2350 \mathrm{~m}\right)$, and (II) Las Tapias de la Legion $\left(24^{\circ} 12^{\prime} 39^{\prime} \mathrm{N}\right.$; $\left.101^{\circ} 7^{\prime} 60^{\prime} \mathrm{O} \approx 2290 \mathrm{~m}\right)$ are located in the close vicinity of the SM-FFPA (fig. 2), an area covered primarily by desert scrub vegetation with only a scarce presence of arboreal elements typical of mixed conifer forests. The other two systems are located in the northwest corner of the area of influence of the FFPA, and are called: (III) San Juan de Carbonerillas $\left(24^{\circ} 29^{\prime} 46^{\prime} \mathrm{N}\right.$; $101^{\circ} 26^{\prime} 28^{\prime} \mathrm{O}$,

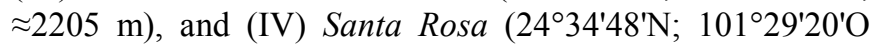
$\approx 2584 \mathrm{~m}$ ) (fig. 2). The vegetation around the former is similar to that near Todos Santos, while in Santa Rosa a mixed conifer forest dominates, with some elements of yucca palms and xeric scrub vegetation.

\subsection{Monitoring of Specimens}

Sampling was conducted from August 14, 2013 to December 14, 2014. It consisted in 9 visits, each of 3-days' duration, to the different localities and was programmed to cover the key times during which the basic reproductive processes and events of this species take place. During monitoring, visual inspections inside the shelters were performed in daytime, and mist nets were placed at entrances at dusk. They were left open for 3 hours to capture individual bats, which were then examined to obtain somatic and reproductive data. The study was conducted under license from Mexico's National Commission for Natural Protected Areas.

\subsection{Identification of the Target Species}

Preliminary identification of the target species was conducted in the field by obtaining external morphological data from live animals. However, because sympatric reports exist for C. townsendii and C. mexicanus in Mexico [13], and because full morphological identification requires measuring skulls, we would have had to sacrifice several specimens, an act that is prohibited by the regulations governing the removal of organisms from Protected Areas or their corresponding zones of influence. Therefore, the decision was taken to determine identification by molecular means. To this end, two bats (one male, one female) were selected from each capture site, and 3-mm diameter biopsies were taken from their wing membrane using a biopsy punch (Fray Products Corp., Buffalo, New York), and then preserved in $70 \%$ ethanol. After that, the bats were released alive.

Total DNA extraction was performed using a kit from the Promega Corporation (Madison, Wisconsin) following the manufacturer's instructions. Amplification of about $800 \mathrm{bp}$ of cytochrome b gene via Polymerase chain reaction [18] was performed using primers L14724 [19] and MVZ-16 [20]. 
Reactions were performed in a volume of $25 \mathrm{ml}$ with approximately $50 \mathrm{ng}$ of DNA, $10 \mathrm{mM}$ of each primer, 200 $\mathrm{mM}$ of each deoxynucleoside triphosphate, $2 \mathrm{mM}$ of $\mathrm{MgCl}_{2}$, and 2.5 units of Taq DNA polymerase (QIAGEN, Inc.). The cycles of the polymerase chain reaction were: $94^{\circ} \mathrm{C}$ followed by 39 cycles of $60 \mathrm{~s}$ at $94^{\circ} \mathrm{C}, 30 \mathrm{~s}$ at $45^{\circ}-50^{\circ} \mathrm{C}$ and $2 \mathrm{~min}$ at $72^{\circ} \mathrm{C}$, with a final extension of $10 \mathrm{~min}$ at $72^{\circ} \mathrm{C}$.

The products of the polymerase chain reaction were purified using the Wizard PCR Prep DNA Purification System (Promega Corporation, Madison, Wisconsin) and utilized to perform sequencing reactions with the Big Dye Terminator Kit (Perkin-Elmer, Norwalk, CT). The sequencing reactions were electrophoresed in an ABI 3100 automated sequencer (Applied Biosystems, Foster City, CA), and sequence alignment was performed with the Clustal W algorithm in the Sequence Navigator 1.0.1 program (Applied Biosystems) and then adjusted manually. Once the sequences were displayed, a basic local alignment -or BLAST [21] was conducted individually to determine the type of species studied based on the amplified DNA segments and calculations of the percentage of similarity between the sequences obtained in this study and similar sequences deposited in the GenBank database [22].

\subsection{Selection of Specimens and Determination of Their Reproductive Status}

To determine the reproductive status of the bats only adult males and females were chosen. The selection criteria included somatic measurements (i.e., body weight, forearm length), the general appearance of the fur, and such skeletal features as complete ossification of the metacarpalphalangeal epiphysis of the $3^{\text {rd }}$ and $4^{\text {th }}$ fingers of the forelimbs, and the degree of tooth wear [10,23].

Each of the captured male specimens we assigned one of the following reproductive categories: (i) spermatogenesis; (ii) epididymal prolonged sperm storage period; and (iii) mating. This classification was based on the position, appearance and degree of development of the testes and epididymides [9-11, 24]. For the female samples, the categories were: (i) mating; (ii) prolonged sperm storage; (iii) pregnancy; and, (iiii) lactation. Distinctions were based on the degree of development of the mammary glands and nipples, and the presence of fetuses detected by palpation and/or evident bulging of the abdominal-pelvic region [9, 10, 25].

Other conditions that define important stages of the female reproductive cycle (such as oogenesis, ovulation, and parturition) were inferred in light of previously recorded sexual data for this species, so as to avoid the need to sacrifice and dissect any bats. After gathering and recording the required data, all bats were returned to their shelters alive.

\section{Results}

The sampling procedure produced a total of 121 adult bats (37 males, 84 females) from the main shelters located in the four mining systems chosen in the region (Tables 1, 2).

\subsection{Molecular Identification of the Species}

Analysis and editing of the sequences obtained from the bats selected for molecular identification confirmed that they were of good quality. Once visualized and edited, fragments of $612 \mathrm{bp}$ of the cytochrome $\mathrm{b}$ gene were analyzed. BLAST analysis [21] made it possible to determine that the sequences gathered showed a maximum identity of $99 \%$ with the sequence deposited in GenBank that is homologous to Corynorhinus townsendii (access number JQ917001), thus confirming that the sequences examined in this study do correspond to the amplified gene for that species. In conclusion: all bats captured at the four sites belonged to the species C. townsendii.

\subsection{Somatic and Reproductive Characteristics of the Bats}

The sex distribution for adult bats of this species from the study area favored females by a ratio of $2.7: 1$. The average values and ranges of the somatic characteristics recorded for the female specimens were as follows: forearm length, 44.1 mm (rank: 39.9-46.3) for all bats caught; and body weight (after excluding the females that were in the different stages of gestation) of $9.7 \mathrm{~g}$ (rank: 8.2-13.1). The females of C. townsendii have one pair of mammary glands located laterally in the thorax (Fig. 3a). Pregnancy was ascertained by palpation through the month of April until mid-May. Most of the females were in the final stage of pregnancy, as shown by obvious bulging of the abdominal-pelvic region caused by the presence of the product. The changes observed in the region around the breasts of the females, together with the degree of nipple development, allowed us to document the various stages of the cycle of the mammary gland, as shown below (Table 1, Fig. 3):

Table 1. Somatic data and reproductive conditions of the adult female C. townsendii bats by date of capture, at the roosts of the four mine systems. BW, body weight; FAL, forearm length; nipple size is the relative size of the mammary gland nipple: inconspicuous, small, medium and large; the symbols $>$ and = denote differences or equality in the number of organs with certain size in the sample of bats. NM, variable not measured; body weight of some pregnant and lactating females was not measured to prevent abortion, or to allow them the early foraging. In the number of bats captured by date ( $n$ ), the number in parenthesis is the total number of specimens in the sample.

\begin{tabular}{ccccc}
\hline & & \multicolumn{2}{c}{ Adult female Corynorhinus townsendii bats } \\
\hline \multirow{2}{*}{ Capture date } & Number of bats $(\boldsymbol{n})$ & Somatic measures (mean and rank) & FAL (mm) \\
\cline { 3 - 4 } & & BW $(\mathbf{g})$ & & Reproductive condition \\
$14 / 08 / 13$ & 3 & 10.1 & 44.1 & Post-lactation inactivity; \\
$19 / 09 / 14$ & 1 & $(8.2-13.1)$ & $(42.3-46.0)$ & nipple size: inconspicuous $>$ small $>$ medium \\
$12 / 09 / 13$ & 6 & & \\
$18 / 10 / 13$ & 20 & & \\
\hline
\end{tabular}




\begin{tabular}{|c|c|c|c|c|}
\hline \multicolumn{5}{|c|}{ Adult female Corynorhinus townsendii bats } \\
\hline \multirow{2}{*}{ Capture date } & \multirow{2}{*}{ Number of bats $(n)$} & \multicolumn{2}{|c|}{ Somatic measures (mean and rank) } & \multirow{2}{*}{ Reproductive condition } \\
\hline & & BW (g) & FAL (mm) & \\
\hline & $\begin{array}{c}2 \\
(32)\end{array}$ & & & \\
\hline $\begin{array}{l}15 / 12 / 13 \\
12 / 12 / 14\end{array}$ & $\begin{array}{l}3 \\
3 \\
(6)\end{array}$ & $\begin{array}{c}9.9 \\
(9.5-10.4)\end{array}$ & $\begin{array}{c}43.8 \\
(41.0-45.1)\end{array}$ & $\begin{array}{l}\text { Late mating period, sperm storage; } \\
\text { nipple size: medium }>\text { small }>\text { inconspicuous }\end{array}$ \\
\hline $05 / 04 / 14$ & 7 & $\begin{array}{c}10.4 \\
(9.0-11.0)\end{array}$ & $\begin{array}{c}44.0 \\
(42.9-45.3)\end{array}$ & $\begin{array}{l}\text { Early gestation; } \\
\text { nipple size: small>medium; }\end{array}$ \\
\hline $\begin{array}{l}05 / 04 / 14 \\
16 / 05 / 14\end{array}$ & $\begin{array}{c}4 \\
4 \\
(8)\end{array}$ & $\begin{array}{c}10.3 \\
(10.0-11.0)\end{array}$ & $\begin{array}{c}44.1 \\
(43.2-45.4)\end{array}$ & $\begin{array}{l}\text { Middle gestation; } \\
\text { nipple size: } \text { medium }>\text { small; }\end{array}$ \\
\hline $16 / 05 / 14$ & 14 & NM & $\begin{array}{c}44.3 \\
(39.9-46.3)\end{array}$ & $\begin{array}{l}\text { Late gestation; } \\
\text { nipple size: } \text { medium }>\text { large; }\end{array}$ \\
\hline $16 / 05 / 14$ & 15 & NM & $\begin{array}{c}43.9 \\
(39.9-46.3)\end{array}$ & $\begin{array}{c}\text { Early lactation; } \\
\text { nipple size: large, whitish, naked mammary glandular area }\end{array}$ \\
\hline $15 / 08 / 13$ & 2 & NM & 46.3 & $\begin{array}{l}\text { Late lactation; } \\
\text { nipple size: large, darkened, naked mammary glandular area }\end{array}$ \\
\hline
\end{tabular}

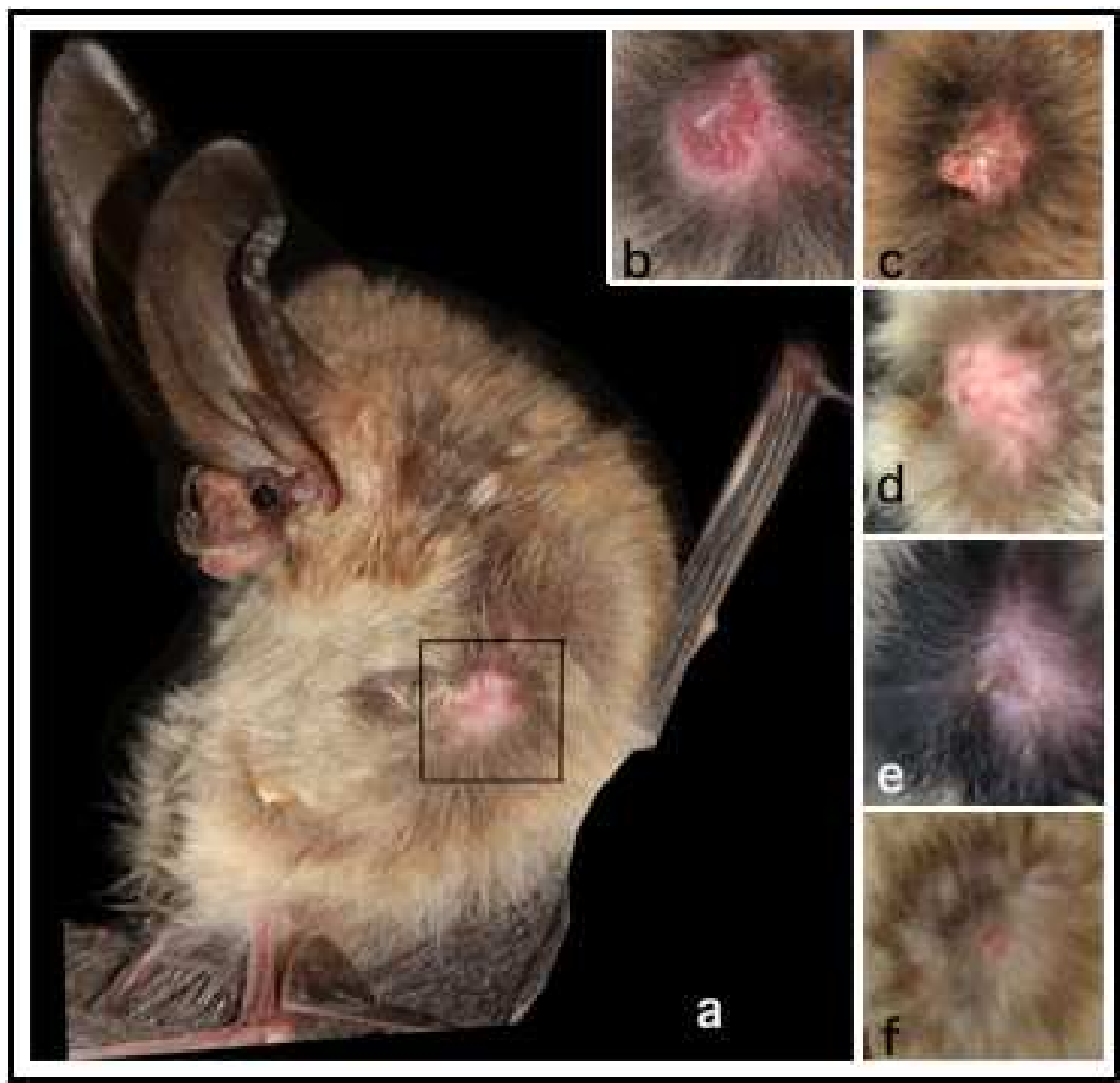

Figure 3. (a) Photograph of an adult female C. townsendii bat caught in middle May, in late pregnancy; the black square locate the pectoral mammary gland, with a well-developed nipple in a naked skin area. The b-f inserts are photographic magnifications of the same region indicated by the square in (a) but from other specimens that correspond to different development stages of the glandular zone and nipples, and show the main stages of the mammary gland cycle. (b) Early pregnancy; the mammary gland cycle restarts (early April). (c) Late pregnancy, (early May). (d) Lactation (since late May). (e) Retrogression of the mammary gland after the weaning of the young; nipple seen cornified and begins an apparent necrosis. (f) Pos-lactation inactivity (since early October), the skin area around the inconspicuous nipple has been re-covered with hair. 
I- Renewal of the mammary gland cycle in early April, during the first trimester of pregnancy; the nipple is small, translucent in appearance, and located precisely in the center of a circular area of glandular tissue reddish in color due to high blood irrigation, with bare skin caused by hair loss.

II- Pre-lactating condition, in the third trimester of pregnancy, which occurs in early May: the nipple is prominent, while the glandular area is swollen but still reddish.

III- Lactation, beginning in the second half of May; the glandular area is clearly turgid and whitish in color due to the presence of milk; the nipple is highly-developed.

IV- Involution of the mammary gland; once weaning of the young occurs (beginning in August), the nipple shows regression by its dark color and cornified skin; the glandular area has a whitish tone, but is no longer swollen, indicating the cessation of glandular activity.

V- Post-lactation inactivity; beginning in October, the area of glandular tissue and the nipple become very small in size, and the skin is once again coated with fur.

For all the male specimens, the study determined the following somatic values: average forearm length, $43 \mathrm{~mm}$ (rank: 41.1-45.0), and mean body weight, $8.8 \mathrm{~g}$ (rank: 7.010.0) (Table 2). Comparison of these measurements with the corresponding values for the non-pregnant females revealed sexual dimorphism for this species, as females are larger than males.
In adult male $C$. townsendii bats, the testes and epididymides are permanently scrotal and located in the inguinal position (Fig. 4c). Since they undergo dramatic changes in size and appearance according to the different phases of the sexual cycle, it was possible to establish the main stages of the male reproductive cycle for the species in the study area, as shown below (Table 2, Fig. 4):

I- Testicular recrudescence; in the first half of May, males have inconspicuous external testes; the epididymis is smallto-medium in length with a thin and elongated appearance; the caudal end of the tunica vaginalis is black in color.

II- Spermatogenesis, from mid-May to late September; in August, the testes are inguinal and project into the tail membrane because they are fully developed; the cauda of the epididymis takes on a globular appearance; the pigmented area expands and becomes light in color, indicating the onset of the sperm storage period.

III- Mating in November-December; the size of the testes decreases again and they become inconspicuous; spermatogenesis has ceased completely; the epididymis is very elongated with a globular tail likely due to the concentration of sperm.

IV- Inactivity, post-winter; in April, both organs -testis and epididymis- are in a recessed condition; the epididymis is still elongated but the tail is no longer globular, indicating that it has finished storing sperm; the tunic covering them is of dark color due to the presence of pigmentation.

Table 2. Somatic data and reproductive conditions of the adult male $C$. townsendii bats by date of capture, at the roosts of the four mine systems. BW, body weight; FAL, forearm length; relative size of the testes and epididymides: inconspicuous, small, medium and large; the symbols $>$ and $=$ denote differences or equality in the number of organs with certain size in the sample of studied bats. NM, variable not measured. In the number of bats captured by date (n), the number in parenthesis is the total number of specimens.

\begin{tabular}{|c|c|c|c|c|}
\hline \multicolumn{5}{|c|}{ Adult male Corynorhinus townsendii bats } \\
\hline \multirow{2}{*}{ Capture date } & \multirow{2}{*}{ Number of bats $(n)$} & \multicolumn{2}{|c|}{ Somatic measures (mean and rank) } & \multirow{2}{*}{ Reproductive condition } \\
\hline & & BW $(g)$ & FAL (mm) & \\
\hline $04 / 04 / / 14$ & 5 & $\begin{array}{c}9.0 \\
(7.0-10.0)\end{array}$ & $\begin{array}{c}41.2 \\
(33.6-44.6)\end{array}$ & $\begin{array}{c}\text { Post-winter inactivity; } \\
\text { testes: inconspicuous; } \\
\text { epididymides: } \text { medium>large, globosely, dark cauda }\end{array}$ \\
\hline $16 / 05 / 14$ & 6 & NM & $\begin{array}{c}42.6 \\
(41.1-44.8)\end{array}$ & $\begin{array}{c}\text { Testicular recrudescence; } \\
\text { testes: small; } \\
\text { epididymides: medium }>\text { large }=\text { small, thin, dark }\end{array}$ \\
\hline $15 / 08 / 13$ & 1 & NM & 41.9 & $\begin{array}{l}\text { Full spermatogenesis; } \\
\text { testes: large; } \\
\text { epididymides: large, thin, dark }\end{array}$ \\
\hline $19 / 09 / 14$ & 1 & NM & 43.0 & $\begin{array}{c}\text { Late spermatogenesis, } \\
\text { epidydimal sperm storage; } \\
\text { testes: large; } \\
\text { epididymides: medium, globosely, clear cauda }\end{array}$ \\
\hline $12 / 10 / 13$ & 11 & $\begin{array}{c}8.9 \\
(8.1-9.7)\end{array}$ & $\begin{array}{c}43.4 \\
(41.9-45.0)\end{array}$ & $\begin{array}{c}\text { Testicular involution, } \\
\text { epidydimal sperm storage; } \\
\text { testes: large }>\text { medium; } \\
\text { epididymides: large }>\text { medium, globosely, clear cauda }\end{array}$ \\
\hline $\begin{array}{l}24 / 11 / 13 \\
13 / 12 / 13\end{array}$ & $\begin{array}{c}1 \\
12 \\
(13)\end{array}$ & $\begin{array}{c}8.6 \\
(7.4-9.6)\end{array}$ & $\begin{array}{c}43.0 \\
(41.8-44.5)\end{array}$ & $\begin{array}{c}\text { Mating period, } \\
\text { epidydimal sperm storage; } \\
\text { testes: inconspicuous; } \\
\text { epididymides: large> }>\text { medium, globosely, clear cauda }\end{array}$ \\
\hline
\end{tabular}




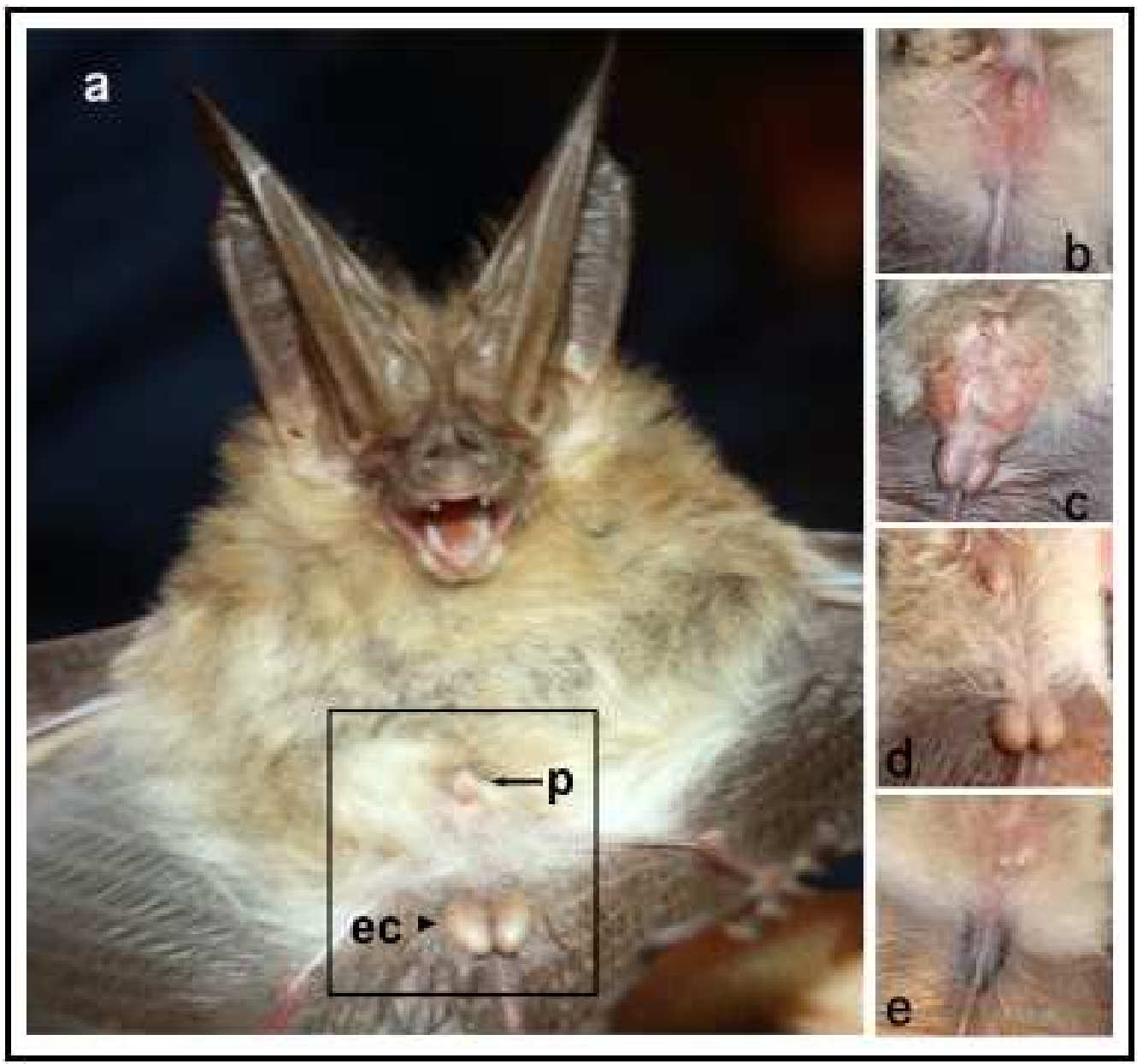

Figure 4. (a) Photograph in ventral view of an adult male C. townsendii bat caught in the mating period of November; the black square locate the penis (p, arrow) and the cauda of the epididymides (ec, arrow head), this last organs placed on the uropatagium, distal to the groin region, along the vertebral tail. The b-e inserts are photographic magnifications of the same region indicated by the square in (a) but from other specimens that correspond to different development stages of the testes and epididymides, and show the main stages of the sexual cycle. (b) A young specimen about 10 months old caught in April, before its first reproductive season, the testes and epididymides are scrotal but almost conspicuous. (c) Full spermatogenesis (August-September), the testes show maximal size; the prolonged sperm storage has started. (d) Mating period (November-December), spermatogenesis is arrested; the cauda of epididymides is congested with sperm. (e) Post-hibernal reproductive inactivity (March-April), the cauda epididymides are short, thin and surrounded by a dark pigmented tunica albuginea.

\section{Discussion}

As mentioned above, the sex distribution of the adult bats in this study favored females by a ratio of 2.7:1, due primarily to the number of females in the gestation-lactation stage, which highlights the importance of the various mining systems monitored that are used as maternal shelters, an aspect that is characteristic of the social organization of the females of this species in U.S. populations [9], and of at least one sister species; namely, C. mexicanus found in central Mexico [26].

Based on the reproductive data gathered in this study, together with the information reported in previous works on C. townsendii $[9,10]$, it was possible to establish all the main reproductive stages for both male and female bats (Fig. 5). The stages that were estimated were: oestrus and subsequent intercourse, which begin in autumn and peak in November, though some copulation continues into February. The sperm are first stored in the cauda epididymis of males from mid-
August to late October, but after insemination storage continues inside the female genital tract from November to late February, when ovulation, fertilization, and pregnancy should occur.

While this study did not determine whether the specimens of C. townsendii from the Mexican Highlands perform true hibernation, the fact that several specimens were captured in the months of November and December as they flew out of their shelters to forage suggests they are characterized by intermittent periods of torpor or, perhaps, that their period of true hibernation occurs in the months of January and February. However, this physiological aspect must be verified through additional studies. As has been reported for several species of vespertilionid bats in temperate zones of America that exhibit delayed fertilization [8] ovulation may occur shortly before, or immediately after, the end of the winter period. In the case of $C$. townsendii, clear evidence of gestation (by palpation) was recorded in early April, after onset of the spring season. In these bats, the gestation period 
can vary from 56-to-100 days, depending on temperatures in the spring and the degree of torpor experienced by individual females. Births occur in late spring or early summer, followed by a period of anoestrus. Determining when oogenesis and folliculogenesis begin again, the time required for full development of the follicles to ovulation, and the moment of fertilization, will only be possible by performing histological studies that require sacrificing specimens, a procedure that is prohibited for species living in recognized Conservation Areas, such as Sierra La Mojonera Flora and Fauna Protection Area, and its hiterland. One alternative could be to monitor hormone levels -especially of the steroid sex type- using non-invasive quantification methods with urine or feces, but these issues require future studies.

In males of $C$. townsendii, spermatogenesis occurs during the summer and reaches its peak in August-September. In late September-early October the testes regress in a process that coincides with the entry of the sperm into the epididymis (Fig. 5). The accessory sex glands decrease completely in size in late October $[9,10]$. One particularly important fact related to the establishment of the full sexual cycle in males is the duration of sperm storage in the epididymis, but determining this would require almost fortnightly monitoring of bats beginning in August when spermatogenesis is complete and continuing until the end of the winter period, when the epididymis regresses [11].

Upon evaluating the data on the seasonality and dynamics of the reproductive processes recognized for Townsend's Big-eared bats in the SM-FFPA and its area of influence, it can be concluded that the reproductive pattern corresponds to that proposed by Pearson et al. [9] for populations of this species in the United States. This pattern that can be characterized as: monoestrous, seasonal, with delayed fertilization and prolonged sperm storage first in the epididymis, and later in the female's reproductive tract. However, because there is no precise correspondence between the dates on which the main reproductive processes of this species occur throughout its area of distribution, it is considered to present an 'emerging' reproductive pattern [4, 5]; with differences in timing most likely due to variations in environmental conditions and variability in the availability of shelters.

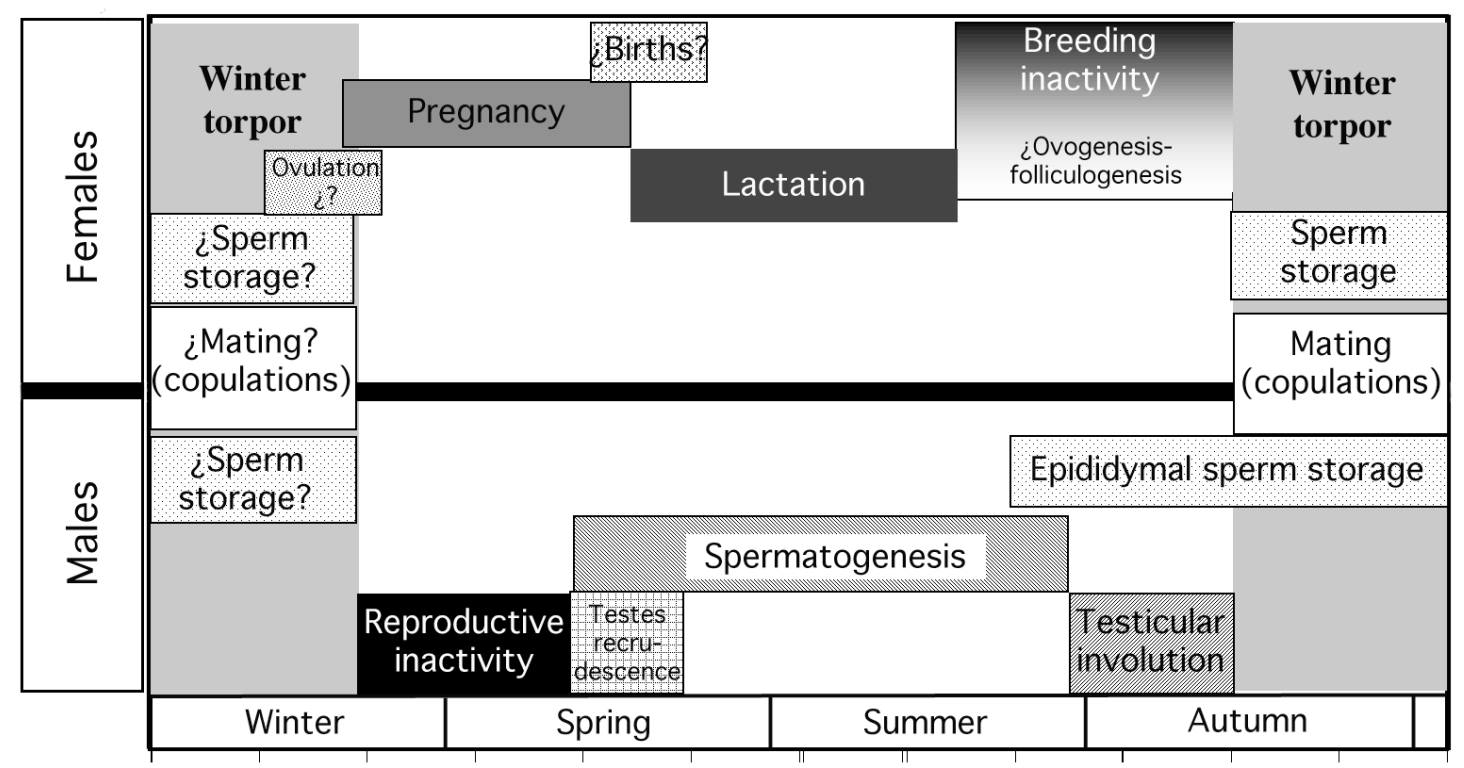

JAN FEB MAR APR MAY JUN JUL AUG SEP OCT NOV DEC

Figure 5. Annual representation of the timing and duration of the main reproductive processes and events, establishing the full sexual cycle of C. townsendii in the SM-FFPA and its influence zone at the Potosino-Zacatecano Highlands of Mexico. Question forms i? of particular reproductive processes or events were estimated by taking into account data about the same species reported in the scientific literature, but also by estimations from our own data in this study

\section{Conclusion}

This study clearly suggests that the four mining systems (Todos Santos, Las Tapias de la Legion, San Juan de Carbonerillas, and Santa Rosa) studied in the Sierra La Mojonera Flora and Fauna Protection Area ant its hinterland, located at the states of San Luis Potosi and Zacatecas in the Central Highlands of Mexico, have great potential for
Corynorhinus townsendii bats in relation to the fundamental processes that make up the sexual cycles of males and females. Hence, this zone must be considered as of high priority for conserving this species of Chiroptera.

\section{Acknowledgements}

The realization of this work was made possible through funding by CONANP (SEMARNAT, MEXICO), with the 
PROMOBI/RNEySMO/sierra-mojonera/04/2014 agreement of its 2014 Biological Monitoring Program; and the full administrative and logistic support of Universidad Autónoma Metropolitana, Iztapalapa. We would like to acknowledge the technical support given by the biologist Aline Méndez Rodríguez, for her advice in the molecular identification of the bat species; and to the MB Osiris Aguilar Romero, for her generous cooperation in the preparation of maps using GIS. Special thanks to Mr. Honorio Pérez Martínez from Huertecillas, Vanegas, SLP, for their great support in the field work.

\section{References}

[1] Sherwin, R.E., D. Stricklan, and D.S. Rogers. 2000. Roosting Affinities of Townsend's Big-Eared Bat (Corynorhinus townsendii) in Northern Utah. J. Mammal. 81(4): 939-947.

[2] López-González, C. 2005. Use of Abandoned Mines by a Community of Temperate Bats in Durango, Mexico. Acta Chiropterologica. 7(2): 285-292.

[3] Fenton, M.B. 1997. Science and the Conservation of Bats. J. Mammal. 78(1): 1-14.

[4] Clark, B.S., K.C. Bryon, and D.M. Leslie, Jr. 2002. Seasonal Variation in Activity Patterns of the Endangered Ozark BigEared Bat (Corynorhinus townsendii ingens). J. Mammal. 83(2): 590-598.

[5] Clark, B.S., D.M. Leslie, Jr., and T.S. Carter. 1993. Foraging Activity of Adult Female Ozark Big-eared Bats (Plecotus townsendii ingens) in Summer. J. Mammal. 74(2): 422-427.

[6] Comizzoli, P., P. Mermillod, and R. Mauget. 2000. Reproductive Biotechnologies for Endangered Mammalian Species. Reprod. Nutr. Dev. 40(5): 493-504.

[7] Krutzsch, P.H. 2009. The Reproductive Biology of the Cave Myotis (Myotis velifer). Acta Chiropterologica, 11(1): 89-104.

[8] Racey, P.A. and A.C. Entwistle. 2000. Life-history and Reproductive Strategies of Bats. In: E.G. Crichton and P.H. Krutzsch, Editors. Reproductive Biology of Bats. Academic Press. London. Pp. 364-414.

[9] Pearson, O.P., M.R. Koford, and A.K. Pearson. 1952. Reproduction of the Lump-nosed Bat (Corynorhinus rafinesquei) in California. J. Mammal. 33(3): 273-320.

[10] Kunz, T.H. and R.A. Martin. 1982. Plecotus townsendii. Mammalian Species. 175: 1-6.

[11] León-Galván, M.A., R. López-Wilchis, O. Hernández-Pérez, E. Arenas-Ríos, and A. Rosado. 2005. Male Reproductive Cycle of Mexican Big-eared Bats, Corynorhinus mexicanus (Chiroptera: Vespertilionidae). Southwest. Nat. 50(4): 453-460.

[12] Handley, C.O. 1959. A Revision of American Bats of the Genera Euderma and Plecotus. Proc. U.S. National Mus. 110.

[13] López-González, C. and L. Torres-Morales. 2004. Use of Abandoned Mines by Long-eared Bats, Genus Corynorhinus
(Chiroptera: Vespertilionidae) in Durango, Mexico. J. Mammal. 85(5): 989-994.

[14] Smith, S.J., et al. 2008. Subspecific Affinities and Conservation Genetics of Western Big-eared Bats (Corynorhinus townsendii pallescens) at the Edge of their Distributional Range. J. Mammal. 89: 799-814.

[15] Pierson, E.D., et al., 1999. Species Conservation Assessment and Strategy for Townsend's Big-eared Bat (Corynorhinus townsendii townsendii and Corynorhinus townsendii pallescens). ed. I.D.o.F.a. Game. Idaho: Idaho Conservation Effort.

[16] Piaggio, J., K.W. Navo, and C.W. Stihler. 2009. Intraspecific Comparison of Population Structure, Genetic Diversity, and Dispersal Among Three Subspecies of Townsend's Big-eared Bats, Corynorhinus townsendii townsendii, C. t. pallescens, and the Endangered C. t. virginianus. Conserv. Genet. 10: 143-159.

[17] Secretaría del Medio Ambiente y Recursos Naturales (SEMARNAT). 2010. Norma Oficial Mexicana NOM-059SEMARNAT-2010, Protección Ambiental -Especies Nativas de México de Flora y Fauna Silvestres-Categorías de Riesgo y Especificaciones para su Inclusión, Exclusión o Cambio- Lista de Especies en Riesgo. Diario Oficial de la Federación, Executive Branch of the United States of México, Mexico City.

[18] Saiki, R.K., et al. 1988. Primer-directed Enzymatic Amplification of DNA with a Thermostable DNA Polymerase. Science. 239(4839): 487-91.

[19] Irwin, D., T. Kocher, and A. Wilson. 1991. Evolution of the Cytochrome b Gene of Mammals. J. Mol. Evol. 32(2): 128144.

[20] Smith, M. and J. Patton. 1999. Phylogenetic Relationships and the Radiation of Sigmodontine Rodents in South America: Evidence from Cytochrome b. J. Mamm. Evol. 6(2): 89-128.

[21] Altschul, S.F., et al. 1990. Basic Local Alignment Search Tool. J. Mol. Biol. 215(3): 403-10.

[22] Benson, D.A.M., et al. 2012. GenBank. Nucleic Acids Res. D48-D5310.1093/nar/gks1299.

[23] Anthony, E.L.P. 1988. Age Determination in Bats. In: T.H. Kunz, Editor. Ecological and Behavioral Methods for the Study of Bats. Smithsonian Institution Press. Washington, DC. Pp. 47-58.

[24] Entwistle, A., P. Racey, and J. Speakman. 1998. The Reproductive Cycle and Determination of Sexual Maturity in Male Brown Long-eared Bats, Plecotus auritus (Chiroptera: Vespertilionidae). J. Zool. 244(01): 63-70.

[25] Vela Hinojosa, C., M.A. León-Galván, M. Tapia-Rodríguez, G. López-Ortega, M.A. Cerbón-Cervantes, et al. 2013. Differential Expression of Serotonin, Tryptophan Hydroxylase and Monoamine Oxidase A in the Mammary Gland of the Myotis velifer Bat. PLoS One. 8(9): e75062.

[26] López-Wilchis, R. 1989. Biología de Plecotus mexicanus (Chiroptera: Vespertilionidae) en el Estado de Tlaxcala, México. Doctoral thesis, Universidad Nacional Autónoma de México, México D.F. 